Scientists are agreed, in the first place, that there has been a dangerous diversion of resources and talent from the really significant long-range concerns of science to the narrower short-range objectives of practical results. Nearly half America's expenditure each year goes to armaments. Economic and social pressures have moved a disproportionate percentage of the inadequate supply of scientists from universities to government and industrial laboratories. Even in American universities, the work of science has become dependent upon income from outside contracts and subject to the outside motivations which such contracts imply. As a result, the careers of an alarming number of the younger generation of scientists are now permanently lost to science. The education of the next generation is jeopardized by the breakdown of science teaching in American high schools and colleges. The future of science has been mortgaged in the eagerness to exploit its past.

Science has come under another kind of duress through preoccupation with national security in the narrow and negative technical sense. of the term. Military secrecy seriously hampers publication and communication in a number of major fields of work. Direct contact between scientists has been disrupted by restriction on the travel of American scientists abroad and the admission of foreign scientists to America. Scientists have been among the most notable victims of the invasion and abuse of personal privacy and dignity which characterize the loyalty and security programme of the Federal Government. Outside any conceivable connexion to national security, the attendant obsession with loyalty has created an atmosphere of fear and conformity which is as obnoxious and stifling to science as to any other branch of free inquiry.

It is impossible to calculate the damage that has been done to the integrity and vitality of the American scientific establishment. "Without doubt we shall pay for it in the future. It will show up in the loss of the advances in technology which should have come from the progress in science we have set aside today."

There is a lesson in this recital. The scientific enterprise cannot be successfully subordinated to merely national ends. Without the long view-the world view-the advance of science must falter and come at last to a halt.

The international tradition runs too deep in the life of science, however, to have been throttled in fifteen years. Among scientists in every field, their personal and professional associations with colleagues abroad, their mutual respect for one another, and the sharing of achievement in significant work establish bonds which outreach the dividing movements of this period. The international community of science still provides us with our most hopeful example of a world polity, in which statesmen and citizens as well as scientists may some day participate.

In the rest of his article Piel points to activities like the International Geophysical Year and the work of the United Nations Technical Agencies as examples of those forces which should serve as hope and encouragement to men of science everywhere.

\section{MODERN CYTOLOGY}

\section{International Review of Cytology}

Edited by G. H. Bourne and J. F. Danielli. Vol. 4. Pp. xii +419 . (New York: Academic Press, Inc.; London: Academic Books, Ltd., 1955.) 9 dollars.

A S usual, Dr. G. H. Bourne and Prof. J. F. A Danielli have selected widely different topies for Vol. 4 of the "International Review of Cytology". While many readers might well ask for more unity, I thoroughly enjoy this non-conformist lack of uniformity. The articles in which I am directly interested are extremely useful and valuable for my research work; the others are no less important for a teacher in general biology.

The first paper, by M. J. Kopac, deals with cytochemical surgery: the list of the methods and the instruments available for quantitative cytochemical investigations on isolated cells or their parts is very complete; but the descriptions are somewhat too short to enable one to utilize them without going back to the original papers. A new "volumetric sub. micromanipulator" and a modified microdilatometric method are described; they should prove useful, but it is perhaps unfortunate that the results obtained so far with them-if there are any-are not mentioned.

After an interesting article on amœebocytes, especially in molluscs, by L. E. Wagge, M. Wolman discusses cytological and cytochemical fixations : the expected conclusion is that even freeze-drying is far from ideal and that there are no good universal fixing-agents. The next two papers, by A. Marshak and by $\mathrm{R}$. Vendrely, deal respectively with bacterial cytology and histochemistry (the latter a rather illchosen title, since bacteria scarcely constitute a tissue in the usual sense). They are well documented, but their very carefulness leaves the reader with a slight feeling of frustration; he will often have to draw his own conclusions.

Next come reviews on plant mitochondria (D. P. Hackett) and the structure of chloroplasts (K. Mühlethaler); we are here on safer ground, and there seems to be little reason to doubt that plant mitochondria strongly resemble animal mitochondria, and that the structurally complex chloroplasts originate from proplastids distinct from the mitochondria. N. B. Kurnick's review on the histochemistry of nucleic acids is very thorough and critical ; although it only deals with the techniques, it should prove very useful.

The article on structure and chemistry of nucleoli, by W. S. Vincent, is clear and contains much new information; the author reaches the conclusion that the nucleolus might be the site of a limiting ratereaction necessary for the maintenance of cytoplasmic syntheses. With H. Moe and R. Couteaux the reader comes back to more orthodox cytology : the former writes about goblet cells, the latter about the localization of cholinesterase at neuromuscular junctions. Both papers are very well illustrated. Finally, E. J. Conway surveys the evidence in favour of a redox pump in the active transport of cations, and shows that this hypothesis adequately explains many facts in yeast cells as well as frog skin, gastric mucosa or plants.

The book is very well produced; the unfortunate consequence is its rather high price. There are extremely fow misprints-usually names of authors quoted in the text or in the bibliography; but why is it that the only two words quoted in French are wrongly spelt?
J. BRACHET 